\title{
CONSEQUENCES OF COVID - 19 ON SMALL BUSINESS BUSSNESS IN SERBIA
}

\author{
Flutra Jahiu \\ Faculty of Business Administration- The State University of Tetovo, flutura.jahiu@ unite.edu.mk
}

\begin{abstract}
The importance of this paper lies in addressing the consequences of the Covid-19 virus on small business in Serbia. As small businesses are the most prevalent in the non-financial sector of Serbia with over $90 \%$ of the total number of enterprises, then it can be concluded that they are even more affected by the pandemic. Because Covid-19 found small businesses by surprise without any prior plan, as well as other areas of social life, its presence has been going on for more than a year. This has led businesses in general and small businesses in particular to face serious problems such as maintaining their liquidity. Therefore, addressing the consequences of the pandemic that these businesses in Serbia are facing today is more than necessary and identifying them would make the way to help them easier. Therefore, the paper uses secondary information from relevant research of local and international organizations with small businesses in Serbia during the pandemic in 2020, and analyzes them in order to identify the biggest challenges faced by these businesses in their business. as a result of the Covid pandemic - 19. The paper not only helps to access support for these businesses, it also indirectly helps to maintain social welfare given the large number of work force engaged in small businesses in Serbia.
\end{abstract}

Keywords: Covid - 19, small businesses in Serbia, the consequences of the pandemic.

\section{Social sciences}

\section{INTRODUCTION}

The introduction of Covid-19 caused shock in all areas of social life around the world, from which Serbia was not spared. Covid-19 in the world caused consequences from its multiple shocks. The first consequences were of a health nature that brought the illness of millions of people as well as the death of a considerable number of them. The blows were also of the social aspect as a result of numerous restrictions by the governments of the states, maintaining distance, self-isolation, etc. keeping us away from each other. But they were also economical with the imposition of restrictive measures such as reduced working hours, work from home that many businesses could not implement, the complete cessation of work in certain periods of time, which resulted in a significant decline in profit which was reflected in many aspects in the work of enterprises. Undoubtedly, the most affected in this situation in Serbia were small businesses as the most widespread businesses in the country. The fact that small businesses were hit hardest by the pandemic is confirmed by a number of researches in this field. While the factors are some of them. Firstly, because small businesses account for over $90 \%$ of the total number of businesses in the non-financial sector in Serbia, small businesses are most affected by the pandemic crisis also due to their way of financing and limited financial reserves, compared to medium and large businesses. Another very important factor is the restrictions imposed by the Serbian government as a safeguard measure to prevent the spread of Covid-19, which largely involved small businesses. For this reason, a number of studies have been conducted on the impact of Covid-19 on the work of small businesses by both local and international organizations, to see the effect of the pandemic on the work of these businesses, the consequences it has caused and the possibility of support. for overcoming their consequences. Serbia took a series of measures to support the 
economy during the pandemic in 2020, and continues to do so, in an effort to maintain economic stability from the effects of Covid-19.

\section{CONSEQUENCES OF COVID-19 ON SMALL BUSINESSES IN SERBIA}

Covid 19 caused great consequences both in terms of health and economy. In terms of health it caused great losses to people, while in economic terms it caused repairable clothing damage to the overall economy of Serbia.

From covid-19 the total number and infected worldwide has reached 110,224,709 people while from $2,441,901$ have found death. In Serbia, the total number of infected is 439,536 , while the number of dead is $4,351 .^{1}$

According to research, in economic terms the pandemic hit small businesses the hardest. They hit them directly individually in different ways, while its consequences were also reflected in the overall economy of Serbia. The consequences were observed especially in those segments where small businesses contribute more, such as. employment rate, make their assessment, participation in BPSH etc. According to data from 2017, small businesses include: $99.2 \%$ of the total number of enterprises, $47.5 \%$ of the total number of employment, $37.4 \%$ of the value and a number of other contributions to the Serbian economy. (Министарство привреде, 2017)

The effects of Covid-19 are expected to be more negative for micro and small enterprises than for medium and large firms and says the research conducted by WORD BANK GROUP in order to research the economic and social impact of Covid-19 in the private sector According to this research, 35\% of the interviewed managers of micro-enterprises in Serbia expect a drop in revenues of more than $80 \%$, compared to $10 \%$ of medium-sized enterprises with the same expectations (World Bank Group, 2020). But how much Covid-19 and harm small businesses in Serbia we will try to extract through the analysis of the results of some research on this issue. Smart Team and Your Business Forum conduct a search on 209 companies from 25 - 29 March 2020 (at the beginning of the pandemic), of which over 92\% of businesses have up to 10 employees, a survey in order to identify the consequences of Covid-19 in the business of micro and small enterprises in Serbia (FORUM ZA ODGOVORNO POSLOVANJE, 2020). According to this research $63 \%$ of respondents stated that before the outbreak of pandemic businesses and tire were in the period of empowerment and control. Over $85 \%$ of respondents think that the pandemic will have a negative effect on these businesses but $50 \%$ of respondents think that the number of employees in this period will not change. About $51 \%$ think that the economic consequences of the pandemic will last up to a year in their businesses, and only $12.4 \%$ characterize that they can overcome without any additional help. Because with the reserves they possess about $87.5 \%$ think that they will be able to survive $1-3$ months.

From the above mentioned displacement we notice that over $80 \%$ of the surveyed businesses are aware of the negative effects of the pandemic on businesses and tire even though the pandemic outbreak and found them in the required stages. They stated that to repair the consequences of their pandemic you would have to arrive in a year, while half of the respondents characterize that the number of workers will close in a long time for connections to the negative effects of the pandemic. Given that the presence of Covid-19 has entered its second year, the time to repair the economy of these businesses will be much longer than a year.

\footnotetext{
${ }^{1}$ Data are taken from the website https://covid19.rs/ dated 22. 02. 2021.
} 
The abovementioned research brings the challenges with these small businesses in Serbia expect to be faced during and after the Covid-19 pandemic, and according to this list in 5 spaces and before are listed these challenges: $80.4 \%$ of the assessments assessed as their consequences pandemic there will be a reduction in demand for their products and services. $61.2 \%$ think that they will not be able to pay their debts to the state, while $45.9 \%$ express concerns about liquidity due to the reduction in the number of buyers $(44.5 \%)$ and lack of fixed assets $(41.6 \%)$, (Graph1). The problem in general is the lack of financial resources that are now reflected in various forms in the business of these businesses.

Graph 1. Most business challenges during the Covid-19 pandemic

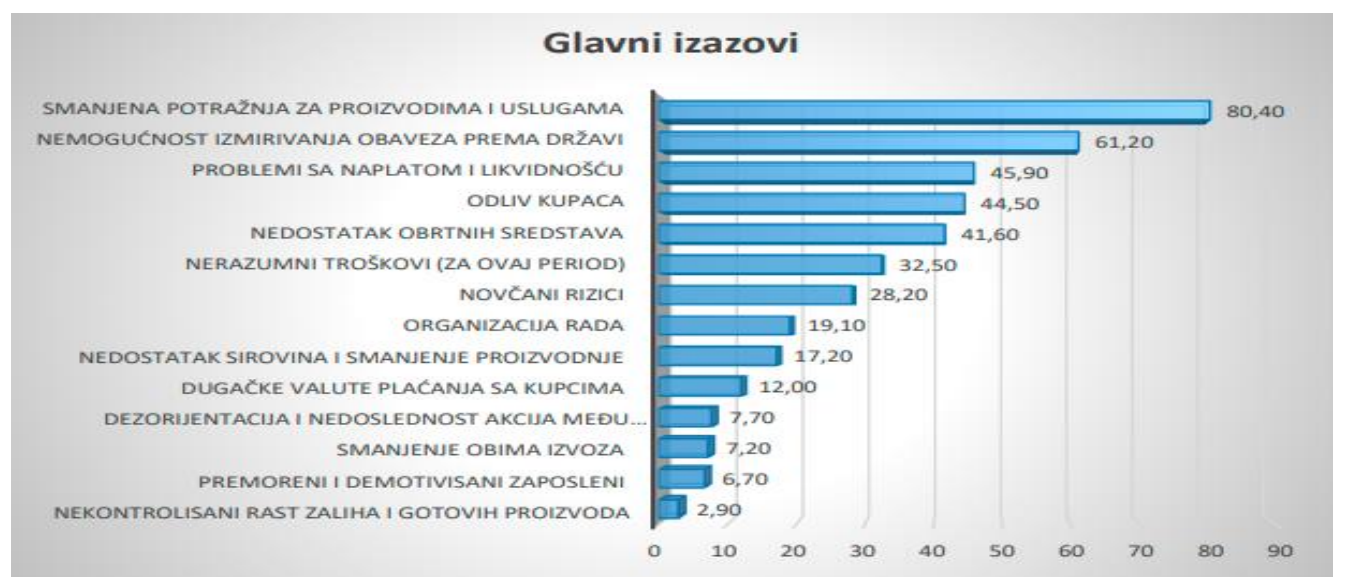

Source: odgovornoposlovanje.rs, 2020.

Also, the USAID Economic Cooperation and Development Project presented in November 2020, which includes a survey of 1000 businesses in Serbia, of which over 90\% are small businesses, once again confirms that business financing is a major problem during the pandemic. This was stated by $69 \%$ of respondents, although the authors of the research state that the Serbian economy has been resistant to Covid19 , given the preservation of the number of employees. From this research it appears that compared to the previous year (2019) even though the number of employees has been maintained (only $11 \%$ have reduced the number of employees) the crisis has had a strong impact on the work of these businesses. Compared to the previous year, in 2020 revenue reductions have marked 50\% of surveyed businesses also 50\% of them have marked net profit reductions. But according to this research, in addition to the negative effects of Covid-19 on the business of some small businesses, there are also positive effects such as e-commerce, in those small businesses that offer online sales. According to this research more than $80 \%$ of companies that have online stores now believe that their online sales are the same or more important than their traditional business, compared to 55\% in 2019. Even in this research like that above, half of the surveyed businesses say that it would take them up to a year to return their business to its previous state (USAID, 2020)

The financial problems faced by small businesses in Serbia as a result of the pandemic are also told in the report published by WB and CEVES in August 2020, which deals with the pandemic crises in the SME sector (CEVES \& WBG, 2020). According to this report, about $64 \%$ of small businesses have stated that they rely on their own reserves, while this figure for large enterprises is half as small, about $34 \%$. While only $5-7 \%$ of small businesses count on credit, this figure is half as small compared to large businesses (14\%). (Graph 2). 
Graph 2. Businesses financial support

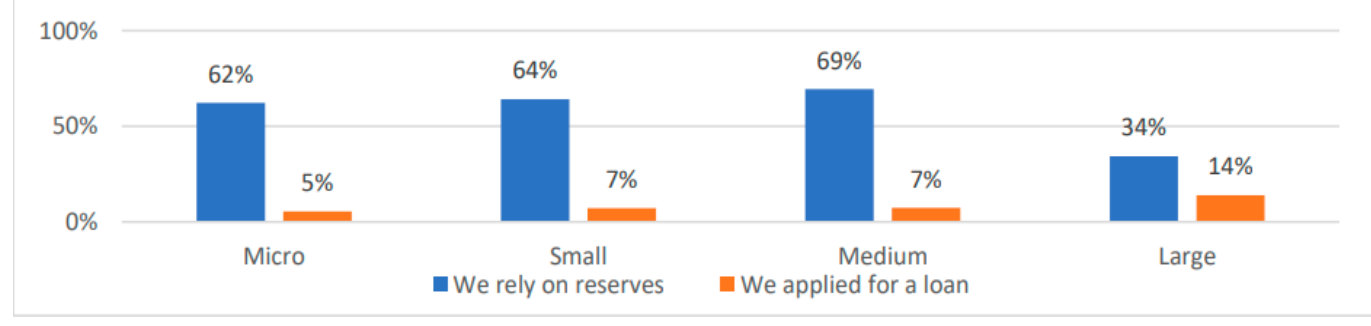

Source: ceves.org.rs, 2020.

According to the report, $11 \%$ of micro-enterprises would reduce the number of employees in the absence of government assistance, this figure for medium-sized enterprises is $14 \%$, while for large enterprises it is only $4 \%$. Given that small businesses have stated that with their reserves they could only

Survive for up to 2 months, and that only $7 \%$ of them count on credit, the only alternative to external financing remains financial support from the government, otherwise it would lead to a reduction in the number of employees but also to the risk of their liquidity.

Another survey by the Union of Employers of Serbia regarding the expectations and challenges from the Covid-19 pandemic in business activities in Serbia, conducted in 462 enterprises in 2020, of which $40 \%$ are up to 10 employees, we extract the following information: $26 \%$ of businesses with up to 10 employees at the time of the interview did not work at all, 35\% worked part-time, $19 \%$ worked fully but outside the enterprise premises and only $20 \%$ of all interviewees worked fully in the enterprise premises. While according to the sectors with the highest percentage that have not worked at all is the sector of hotel (22.0301.05.2020), tourism and gastronomy services with $72 \%$, textile industry $41 \%$ and real estate trade $35 \%$. While the enterprises of the food industry $50 \%$ worked the most, and the enterprises of agriculture, forestry and wood processing $42 \%$. Also $88 \%$ of these companies stated that they have changed the working model or the provision of services to protect the business from Covid-19. 1/3 of these companies think that it takes up to three months to completely rebuild their business while this time of the larger companies is smaller, up to one month. Regarding the insurance of companies, only $18 \%$ of enterprises with up to 10 employees claim that they were insured before the crisis. Also $65 \%$ of the mentioned businesses state that the level of influence of Covid-19 on them is high. $63 \%$ of businesses with up to 10 employees state that they do not have their own financial means or access to other external financing alternatives for which they would help revive the enterprise (Унија послодаваца Србије, 2020) As for the challenges they face as a result of covid-19, they have said; hitting buyers and reducing demand as a result $(65 \%)$, total revenues to maintain the existing level of employment and business (58\%), hitting business partners and unusual cooperation with them (42\%) etc. The consequences of Covid-19 on small businesses and of them in the entire Serbian economy are evident. And to prove them, in the absence of specific statistics for small businesses in 2020, we used statistics for general economic movements in Serbia in 2020 such as- in 2020 employment as young entrepreneurs or employed by them has increased by $2.0 \%$ compared to 2019. The same in 2019 compared to 2018 has increased by 3.6\% (RZS R. Srbije, 2019) So in 2020 there is a decrease in employment growth of this type by $1.4 \%$ - BPSH in 2020 has marked a real decline of $1.1 \%$ compared to 2019.- Also Gross Value Added in 2020 compared to 2019 has decreased by 1.5\% (RZS R. Srbije, 2020). All macroeconomic indicators have declined in 2020 compared to the previous year as a result of the crisis caused by Covid-19. 


\section{GOVERNMENT ECONOMIC SUPPORT PROGRAMS DURING COVID-19 PANDEMIC}

Due to the major negative impact of the Covid-19 pandemic on business in Serbia, and consequently on the overall economy during 2020, the Government of Serbia has approved and implemented two packages of measures to support the economy and conservation. of jobs in which small businesses have been involved and supported. The first package in order to reduce the effects of the pandemic was approved in March 2020 and includes a series of assistance to small businesses, worth 608.3 billion dinars or $11 \%$ of GDP (ING-PRO, 2020).

The second package approved in July 2020 is worth 66 billion dinars. This package includes two payments of $60 \%$ of the minimum wage for all employees in economic entities and the postponement of payment of taxes and contributions for one month (MINISTARSTVO FINANCIJA R. Srbije, 2020).

On February 12, 2021, the government approved the third package of assistance to citizens and the economy worth 249 million dinars, with direct assistance to all businesses, including small businesses of all sectors in order to maintain the liquidity of the private sector. (Razvojna agencija Srbije, 2021)

Also, the Ministry of Economy in February 2021 has published the public call for three support programs for the SME sector and the enterprise for maintaining liquidity, in the form of non-repayable assets and loans, with a total value of 450 million dinars (Ministarstvo privrede, 2020).

\section{CONCLUSION}

From the analysis of the research results included in this paper during 2020 in a pandemic situation it can be concluded that small businesses were the most affected by the medium and large ones, due to their greater extent in all sectors, limited financial resources and lack of adequate financing alternatives.

The hardest hit sectors were the hotel and tourism, gastronomy, textile and real estate sectors. The sector that grew was the food industry and online commerce.

Given that among the biggest challenges facing small businesses in Serbia precedes the reduction of demand for products and services due to the decline in the number of buyers, as a result of this liquidity risk, lack of fixed assets and decline and cooperation with partners, the request for financing of these businesses is the only alternative for maintaining business. Since only $5 \%$ of small businesses can count on financing through loans, the only alternative remains external financing, respectively financial support from the state. State strategies for supporting small businesses must first be oriented towards maintaining the number of employees in these businesses. Maintaining the number of employees reflects on maintaining purchasing power, while this reflects on maintaining profit, respectively maintaining liquidity .The Serbian government managed, through economic support programs, to maintain the number of employees within it. But, as we enter the second year of the pandemic, economic support programs need to be both more planned and financially rich. They should especially be oriented to the most affected sectors but without overlooking other sectors .Small businesses, on the other hand, should try to adapt to the circumstances. Since online commerce has borne fruit in these circumstances, businesses that can set up online stores should create and use that site as the only opportunity in these circumstances. Adequate planning by both the businesses themselves and the state would enable sustainability until the pandemic is overcome, because the demand for goods and services, although reduced, cannot be stopped. Adequate coordination of circumstances, small businesses and the state is therefore the only solution in dealing with the consequences of the pandemic. 


\section{REFERENCES}

1. The COVID-crisis and Serbia's SMEs: Assessment of Impact and Outline of Future Scenarios, (2020). Beograd. CENTER FOR ADVANCED ECONOMIC STUDIES. Linku: https://ceves.org.rs/wp-content/uploads/2020/11/WB-Covid-19_-Report-final.pdf. vizituar: (14. 01. 2021).

2. Posledice pandemije korona virusa na poslovanje malih i mikro preduzeća u Srbiji, 2020. Beograd. FORUM ZA ODGOVORNO POSLOVANJE. Linku: https://odgovornoposlovanje.rs/wpcontent/uploads/2020/04/MMSP-analiza Posledice-pandemije-na-poslovanje SK-i-FOP.pdf vizituar: (11. 12. 2020).

3. Нови пакет економских мера за очување радних места и привредне активности, 2020. Beograd. MINISTARSTVO FINANCIJA. Linku: https://www.mfin.gov.rs/aktivnosti/mali-novi-paket-ekonomskih-mera-za-ocuvanje-radnihmesta-i-privredne-aktivnosti/. (Vizituar: 13. 01. 2021).

4. UASID-OV PROJEKAT SARADNJE ZA EKONOMSKI RAZVOJ, Anketa "1.000 preduzeca ", novembar 2020 godine, USAID. Linku: PowerPoint Presentation (saradnja.rs) (Vizituar: 07. 01. 2021).

5. КРЕДИТИ ЗА ЛИКВИДНОСТ СОVID - 19 ТУРИЗАМ, УГОСТИТЕЉСТВО И ПУТНИЧКИ САОБРАһАЈ, 2020. Beograd. Ministarstvo Privrede. Linku: https://privreda.gov.rs/200-miliona-evra-povoljnih-kredita-za-likvidnost-i-obrtna-sredstvaprivrednih-subjekata/

6. ИЗВЕШТАЈ О МАЛИМ И СРЕДЮИМ ПРЕДУЗЕЋИМА И ПРЕДУЗЕТНИШТВУ, 2017. Beograd. Министарство привреде. Linku: https://privreda.gov.rs/wpcontent/uploads/2019/01/Izvestaj_MSPP 2017.pdf (Vizituar: 24. 11. 2020).

7. Program ekonomskih mera za podršku privredi Srbije pogođenoj posledicama epidemije (korona virus - COVID-19), 2020. Beograd. ING-PRO. LINKU: https://www.propisi.net/program-meraza-pomoc-privredi-srbije-pogodjenoj-posledicama-epidemije-korona-virus-covid-19/. (Vizituar: 12. 01. 2021).

8. Ekonomski i socijalni uticaj COVID-19, PRIVATNI SEKTOR, ZAPADNI BALKAN REDOVNI EKONOMSKI IZVJEŠTAJ br.17 | proljeće 2020. WORLD BANK GROUP. Linku: http://pubdocs.worldbank.org/en/168321591340102093/WBRER17-12-Private-Sector-BOS.pdf. (Vizituar: 03. 02. 2021).

9. Анкета о радној снази у Републици Србији, 2019. Beograd. Републички завод за статистику. Linku: https://publikacije.stat.gov.rs/G2020/Pdf/G20205658.pdf (21. 12. 2020).

10. Vlada usvojila treći paket mera podrške privredi i građanima. Razvojna agencija Srbije. 2020. Linku: https://ras.gov.rs/vlada-usvojila-treci-paket-mera-podrske-privredi-i-gradanima (Vizituar: 20. 02. 2021).

11. Covid-19.rs. Linku: СТАТИСТИЧКИ ПОДАЦИ О КОРОНА ВИРУСУ - COVID-19 (vizituar: 22.02.2021).

12. Економска кретања у Републици Србији, 2020 (процена). Republicki zavod za statistiku. Linku: https://www.stat.gov.rs/vesti/20201230-ekonomska-kretanja-2020/ (Vizituar: 29. 01. 2021).

13. Утицај пандемије на активности предузећа у Србији: ИЗАЗОВИ И ОЧЕКИВАҢА. Унија послодаваца Србије. Linku:https://drive.google.com/file/d/1oxElSqLaUB8mibQV06xMZW77L5hrTurA/view (Vizituar: 11. 02. 2021). 